\title{
Pelos interiores - a invenção do caipira: cultura, tradição e cozinha
}

\begin{abstract}
Resumo
Inseridos numa perspectiva da história cultural, estes escritos focalizam a polêmica em torno do caipira e da cultura caipira, tendo como foco central a produção de Cornélio Pires (publicações, composições, registros sonoros, espetáculos, ações de divulgação). A cultura caipira é aqui identificada como modo de ser e de viver do homem do campo na área denominada de Paulistânia (ELLIS JUNIOR, 1951; CANDIDO, 2010), que incorpora Vale do Paraíba (Rio de Janeiro e São Paulo), se estendendo pelo oeste do estado de São Paulo (Piracicaba/Tiete/Pirapora), e atingindo o sul de Minas Gerais e Mato Grosso e norte do Paraná. O desafio da análise é discutir a construção cultural do caipira, rastreando suas representações imagéticas, os debates em torno da figura do Jeca, bem como, focalizar gostos, hábitos, práticas e tradições alimentares dos caipiras, privilegiando as décadas iniciais do século XX.
\end{abstract}

Palavras-chave: Cultura Popular. Pires, Cornélio, 1884-1958. Culinária Brasileira.

\author{
Maria Izilda Santos de Matos \\ Doutora em História Econômica pela \\ Universidade de São Paulo (USP). Estagio \\ Pós-Doutoral na Université Lumiere Lyon \\ 2/França. Livre-docente e Professora Titular \\ na Pontifícia Universidade Católica de São \\ Paulo (PUC/SP). Apoio CNPq. \\ Sao Paulo, SP - BRASIL \\ mismatos@pucsp.br \\ orcid.org/0000-0002-4109-3747
}

\section{Elton Bruno Ferreira}

Doutor em História Social pela Pontifícia Universidade Católica de São Paulo (PUC/SP). Apoio CNPq. Sao Paulo, SP - BRASIL eltonbrunonet@yahoo.com.br orcid.org/0000-0002-6267-8314

\section{Para citar este artigo:}

MATOS, Maria Izilda Santos; FERREIRA, Elton Bruno. Pelos interiores - a invenção do caipira: cultura, tradição e cozinha. Tempo e Argumento, Florianópolis, v. 11, n. 27, p. 192 220, maio/ago. 2019. 


\title{
By the interiors - the invention of the caipira: culture, tradition and cuisine
}

\begin{abstract}
Inserted in a perspective of cultural history, these writings focus on the polemic around the caipira and the caipira culture, having as central object of analysis the production of Cornélio Pires (publications, compositions, sound records, shows, publicity actions). The "caipira culture" is here identified as the way of being and living of the man from the countryside in the area known as Paulistânia (ELLIS Junior, 1951. CANDIDO, 2010), which incorporates Vale do Paraíba (Rio de Janeiro and São Paulo), extending to the west of the State of São Paulo (Piracicaba/Tiête/Pirapora), reaching the south of Minas Gerais and Mato Grosso and north of Paraná. The challenge of the analysis is to discuss the cultural construction of the caipira, tracing its representations, the debates around the figure of the Jeca, as well as focusing on tastes, habits, practices and food traditions of the caipiras, giving priority to the early decades of the twentieth century.
\end{abstract}

Keywords: Cultura popular. Pires, Cornélio, 1884-1958. Culinária brasileira.

Estes escritos se propõem a discutir a construção cultural do caipira privilegiando as décadas iniciais do século XX. Primeiramente, observam-se as representações do caipira nas artes plásticas, particularmente na obra de Almeida Júnior, e são rastreadas algumas questões das polêmicas que polarizaram as representações do caipira, destacando as ações de Cornélio Pires que assumiu o papel de promotor-porta-voz da cultura dos interiores através de publicações, composições, registros sonoros/gravações, 
espetáculos, ações de divulgação. Por fim, centrando a análise nos escritos do Pires, focalizam-se gostos, hábitos, práticas e tradições alimentares dos caipiras.

Desde os finais do século XIX, a expansão cafeeira no estado de São Paulo provocou uma ampla demanda de braços, num momento de crise do escravismo, suscitando discussões em torno da questão do trabalho. A elite paulista formulou um projeto, que institucionalizou uma política de imigração subsidiada pelo Estado, em massa, contínua e familiar. Neste mesmo momento, o pintor paulista Almeida Junior ${ }^{1}$, articulando estilo original e competência técnica, priorizou em sua produção as representações do caipira - numa obra que explicitava força renovadora e ineditismo, privilegiando o realismo e a temática regional.

O Caipira Picando Fumo (1893) apresenta o personagem vestido rusticamente, camisa de algodão desabotoada expondo o peito, calças arregaçadas, mostrando partes das pernas, e pés descalços. Na fisionomia se destaca a cor bronze avermelhada (podendo ser pela exposição ao sol na sua faina cotidiana na roça, ou denotando as marcas de miscigenação), se acentuando a despreocupação e desleixo, cabelos desalinhados, bigode e barba rala.

No conjunto, a pintura reforça a intenção do artista de representar o modo de vida dos interiores, posicionando o protagonista sentado em troncos de madeira como degraus de acesso à casa de pau a pique, habitação rústica com mostra do reboco descascado. A observação desperta um estado de mansidão; o caipira com a faca na mão picando o fumo de corda (denotando movimentos lentos e repetitivos); na orelha esquerda a palha, para a composição do cigarro (SANCHES, 2010). ${ }^{2}$

\footnotetext{
1 José Ferraz de Almeida Júnior (1850/Itu/SP-1899/Piracicaba/SP) foi pintor, estudou na Academia de BelasArtes, recebendo reconhecimento e premiações, aperfeiçoou-se na Escola Superior de Belas Artes, em Paris (1876-1882). Voltando ao Brasil, expôs com sucesso e se instalou em São Paulo (1883), sempre realizando viagens à Europa (1891/96). Seu estilo mesclou influências românticas, realistas e préimpressionistas; destacam-se entre seus quadros sobre a temática caipira: o Derrubador brasileiro (1879), Descanso do modelo (1882), Caipira picando fumo (1893), A Partida da Monção (1897), Leitura (1892), 0 Importuno (1898), O violeiro (1899) e Saudades (1899). Cabe observar que as diferentes interpretações sobre o caipira perpetuadas nas telas do autor apresentam sinais positivos, evidenciando uma necessidade de busca das origens agrárias (AMARAL; LOUREIRO, 2000).

2 Para a análise das pinturas de Almeida Júnior, foram inspirações metodológicas as obras de BARTHES, 1964; MANGUEL, 2008; COLI, 2005; JOLY, 1996; PAIVA, 2004; PEREIRA, 2012.
} 


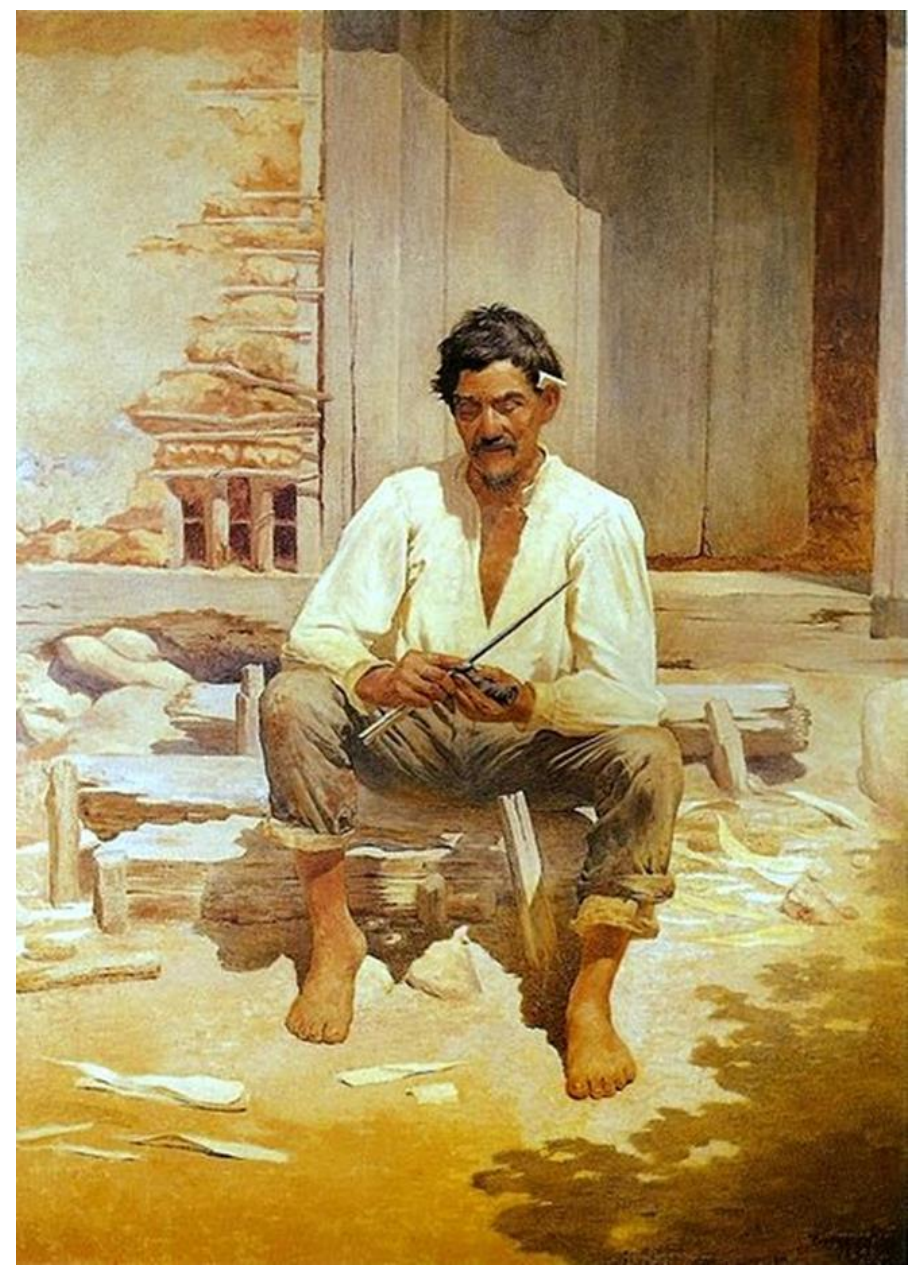

Imagem 1: Caipira picando fumo, de Almeida Júnior,1893.

Os proponentes do projeto imigrantista idealizaram um imigrante laborioso, vigoroso, disciplinado, que representasse o progresso e que reabilitasse o ato de trabalhar, acrescentando como benefício a possibilidade de "caiar" o país. No correr do processo, se para alguns deslocados foi possível atribuir adjetivos como: 'laboriosos', 'ordeiros' e 'dedicados', em outros casos, as características que melhor os qualificaram foram 'lutadores', 'contestadores', 'inconformados com as injustiças sociais', representações que se ampliaram frente à atuação dos imigrantes nos movimentos operários e manifestações no campo e nas cidades. Particularmente, depois das greves de 1917-19, difundiram-se medidas que visavam o controle, com ações de restrição às entradas e retirada dos considerados "indesejáveis", ampliando os conflitos étnicos, xenofobia e preconceitos. 
Nos anos de 1920, se constituiu um ambiente frutífero para a discussão do estatuto da nação e da nacionalidade, questões que se fizeram presentes no Movimento Modernista (1922), que além de uma manifestação artística e intelectual, adquiriu conotações políticas de contestação à situação vigente (CAMARGOS, 2002). A questão do nacionalismo tornou-se um ponto emblemático para a intelectualidade, que em diferentes perspectivas expressou suas concepções.

Entre vários outros aspectos, problematizava-se a presença dos estrangeiros, denunciava-se o caldeamento cultural e os perigos da miscigenação acirrando as discussões (ABUD, 1985; SCHWARCZ, 2005). Neste quadro, se expandiu e se institucionalizou a eugenia, que foi identificada como símbolo de modernidade cultural, expressão de cientificidade, vinculada às noções de evolução, progresso e civilização, propostas convergentes com o imaginário das elites paulistas.

Os debates eugenistas não se limitaram aos círculos médicos, encontravam-se entre seus propagadores e seguidores políticos, juristas, intelectuais e higienistas (CASTANEDA, 1997, DIWAN, 2003; MARQUES, 1994; SOUZA a, 2006). A difusão desse ideário ocorreu pela imprensa (Jornal do Comércio, O Estado de São Paulo, Correio Braziliense), através da publicação de livros, folhetos e artigos em revistas científicas (Boletim de Eugenia), além de conferências, debates e campanhas, como as de luta contra o alcoolismo, doenças venéreas e tuberculose (MATOS, 2018).

Considerado como o que melhor expressou os anseios dos eugenistas e seu principal mentor, Renato Kehl difundiu suas ideias, que buscavam aprimorar a raça, eliminar elementos de degeneração, reabilitar a saúde física, moral e intelectual do povo, destacando a importância da luta pela regulamentação do controle seletivo da imigração (STEPAN, 2005; SOUZA, 2006 a).

Monteiro Lobato se entusiasmou com os preceitos da eugenia, trocando missivas com Renato Kehl, a quem denominava de "D. Quixote científico"3; os contatos se intensificaram nos anos 1920, quando o eugenista publicou A Esterilização sob o Ponto de Vista Eugênico (1921), mesmo período em que Lobato caracterizaria o Jeca Tatu.

\footnotetext{
${ }^{3}$ Carta enviada a Renato Kehl, em 8 de julho de 1929. In: (NIGRI, 2011).
} 
Este funesto parasita da terra é o CABOCLO, espécie de homem baldio, seminômade, inadaptável à civilização, mas que vive à beira dela na penumbra das zonas fronteiriças. À medida que o progresso vem chegando com a via férrea, o italiano, o arado, a valorização da propriedade, vai ele refugiando em silêncio, com o seu cachorro, o seu pilão, a pica-pau e o isqueiro, de modo a sempre conservar-se fronteiriço, mudo e sorna. Encoscorado numa rotina de pedra recua para não adaptar-se. (LOBATO, 2010, p. 161)

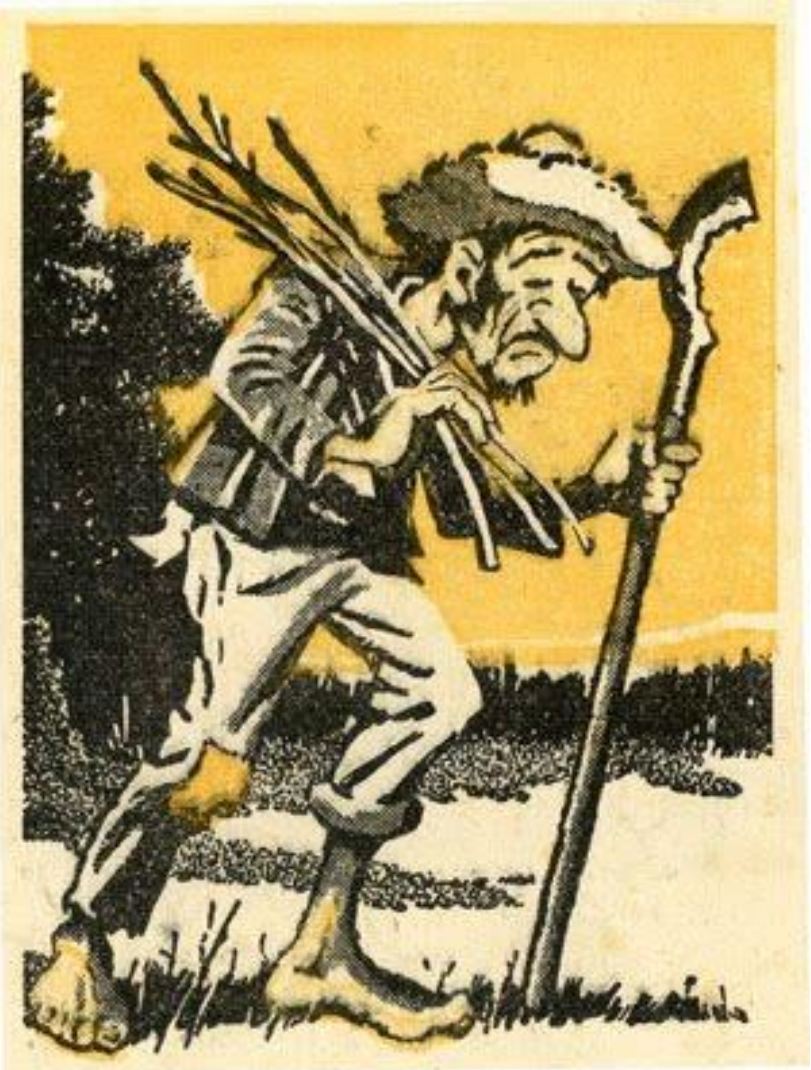

Imagem 2: Capa do Almanaque Jeca Tatuzinho, de Monteiro Lobato, $12^{\mathrm{a}}$ edição, 1941.

Deste modo, reforçava as características negativas do Jeca (alheio à ideia de pátria, indolente, apático, impenetrável à civilização) desencadeando polêmicas. Posteriormente, Lobato reviu sua visão no artigo “Jeca Tatú, a ressurreição”, incluído no livro Problema Vital (1924), prefaciado por Renato Kehl4.

\footnotetext{
4 Destaca-se que depois da publicação da crônica Urupês (no jornal O Estado de São Paulo/1914 e em livro no ano de 1918), o autor percorreu várias posições sobre o homem dos interiores, relativizando suas certezas. O contato com os renomados médicos-sanitaristas Belizário Pena e Artur Neiva (com a publicação do Relatório Médico-Científico e do livro de Pena O saneamento do Brasil) que discutiam as condições sanitárias das populações rurais, levou Lobato a penitenciar-se criando o personagem Jeca Tatuzinho (1924), que ensinava noções de higiene e saneamento às crianças (LAJOLO, 2000).
} 
Na busca pelas "raízes autênticas" da nação e de seu povo, em oposição às representações negativas do Jeca, diferentes vertentes identificaram o homem interiorano (sertanejo, caipira, caboclo) como trabalhador, forte, inteligente, arguto, maleável, dócil, sentimental, afetivo e sincero, apesar de intimidado no meio urbano. Desde 1917, quando publicou o poema Juca Mulato (PICCHIA, 1921), Menotti Del Picchia apresentava um caboclo "forte como a peroba e livre como o vento", reconhecendo-o como elemento original e integrador do nacional. O ano de 1928 foi emblemático, com as publicações de Retrato do Brasil, de Paulo Prado; Macunaíma, de Mário de Andrade; Cobra Norato, de Raul Bopp e Martim Cererê, de Cassiano Ricardo (RICARDO, 1925; RICARDO, 1928; VELLOSO, 1983; LUCA, 2011; ZEM EL-DINE, 2010; OLIVEIRA, 2002).

Neste contexto polêmico, Cornélio Pires assumiu o papel de promotor e porta-voz da cultura caipira; além das publicações, coletou e organizou registros sonoros e gravações, montou espetáculos (com encenações, apresentando violeiros e grupos musicais) e viabilizou a divulgação da cultura do interior pelo rádio.

No bojo dessas polêmicas se constitui a invenção do caipira. A categoria invenção está aqui posta no sentido de se questionar a existência de uma essência identitária5, subentendendo um processo de criação cultural, pleno de sentidos, disputas e tramas de poder. Esse complexo processo contém múltiplas variações, através dos tempos, nos diferentes espaços, com posições, trajetórias e objetivos variados, cabendo destacar que se considera não a invenção, mas, as invenções com toda a pluralidade de significados (MATOS, 2007).

\section{Defesa do caipira: a produção de Cornélio Pires}

Meio escritor, meio ator, meio animador; generoso, combativo, empreendedor, simpático - a sua maior obra foi a ação nos palcos nas palestras na literatura falada que perde bastante quando é lida. Como os oradores, como certo tipo de poetas, como os repentistas e os velhos glosadores de mote, a dele foi uma literatura de ação e comunhão direta, eletrizante, com o público. (CANDIDO, apud DANTAS, 1976, p. 11-12)

\footnotetext{
${ }^{5}$ Apesar de que Cornélio as classificava por recortes étnicos, identificando diferentes caipiras: "branco", "caboclo", "preto", "mulato" e "caipira imigrante".
} 
Denominado “Bandeirante do folclore paulista”, Cornélio Pires nasceu em Tietê (13 de julho de 1884), no interior de São Paulo. Desde a infância, ele se encontrava arraigado à cultura da sua região natal; suas matrizes culturais foram adquiridas pelas andanças, escutando os "causos", histórias contadas em rodas de conversas e músicas cantadas ao som da viola. Habilmente, ele se apropriou dessas experiências (hábitos, costumes, crenças, casos, lendas e linguagem) em suas gravações, canções e interpretações (LEITE, 1996; FERREIRA, 2017).

No começo dos novecentos, Cornélio se mudou para São Paulo, ficando hospedado na pensão da sua tia, Belisária. O jovem ambicionava cursar a Faculdade de Farmácia, mas, sem sucesso em seu intento, empregou-se no jornal O Comércio de São Paulo. Também atuou como revisor em O Estado de S. Paulo e no periódico O Pirralho, em 1914. Foi nessa época, dedicando-se ao estudo e divulgação da cultura dos interiores, que principiaram seus escritos. Em 1910, publicou Musa Caipira, sua primeira coletânea de poesias, com destaque para soneto Ideal caboclo:

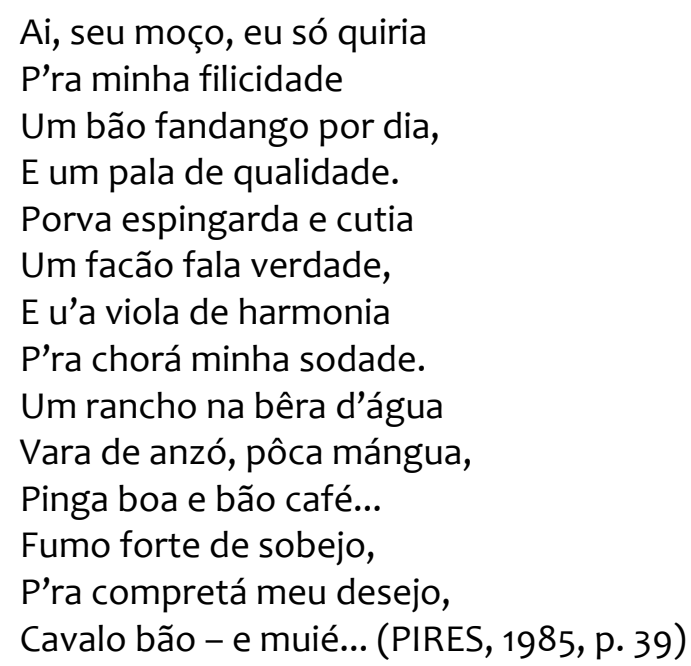

Naquele momento, apresentou no Colégio Mackenzie um espetáculo que reunia catireiros, cururueiros e duplas de cantadores do interior. Nessas exibições, Cornélio, com o seu cigarro de palha em punho, recriava personagens que contavam causos, era como um artifício para garantir autenticidade e identificação com o caipira. 
Em 1939, avaliava ter vendido cerca de um milhão de livros, apontando que os editores praticavam os "milagres da multiplicação", aludindo à possibilidade desse número ser muito superior. Afirmava que o sucesso de vendagem das obras ${ }^{6}$ se devia à forma como escrevia - para os "não letrados", com o uso de linguagem simples e capítulos curtos.

Exemplares foram as obras As estrambóticas aventuras do Joaquim Bentinho (1924) e A continuação das estrambóticas aventuras do Joaquim Bentinho (1929), nas quais o personagem central, Joaquim Bentinho, foi representado como um contador de causos, descrito como:

Baixinho, miudinho, desnalgado, perninhas finas e canelas luzidias, brilhantes aos reflexos do fogo, ao pé do qual nos reunimos todas as noites, O Joaquim Bentinho é um serelepe, espertinho e perereca... (PIRES, 2004, p. 29)

Nas diversas ocasiões em que contava os causos, Cornélio incorporava esse personagem - Joaquim Bentinho, reproduzindo sua forma de falar, constituindo uma narrativa na qual as situações e as questões eram colocadas remetendo às práticas no meio rural, marcadas pela simplicidade e criatividade de causos surpreendentes. O caipira era representado de forma contrastante em algumas situações como ingênuo, autêntico, sábio; em outras, como astuto, mentiroso, hábil, através de ações que visavam envolver e divertir, possibilitando apropriações e reconstruções do receptor/leitor/ouvinte.

Em 1920, Cornélio Pires já atuava na organização de espetáculos, nos quais apresentava anedotas, músicas e encenações acaipiradas. Entre os anos de 1929 e 1930, desenvolveu um trabalho de gravação sonora (discos de $78 \mathrm{rpm}$ ), a partir do qual ampliou suas ações enquanto agente de divulgação da cultura caipira.

\footnotetext{
${ }^{6}$ Musa caipira (1910), O monturo (1911), Versos (1912), Tragédia cabocla (1914), Quem conta um conto (1916), Cenas e paisagens da minha terra (1921), Conversas ao pé do fogo (1921), As estrambóticas aventuras do Joaquim Bentinho (1924); Patacoadas, anedotas, simplicidade e astúcia de caipiras (com "algumas" de estrangeiros) (1926); Seleta caipira (1926), Almanaque d'O Sacy (1927), Mixórdia, anedotas e caipiradas (1928), Meu Samburá-anedotas e caipiradas (1928), A continuação das estrambóticas aventuras do Joaquim Bentinho (1929), Tarrafadas (1932), Sambas e cateretês (1932), Só rindo (1934), Tá no bocó [...] anedotas colhidas escolhidas catadas e adaptadas, variedades e curiosidades (1934), Quem conta um conto [...] e outros contos (1934), Coisa d'outro mundo (capa assinada por Belmonte, 1944), Enciclopédia de Anedotas e Curiosidades (1945).
} 


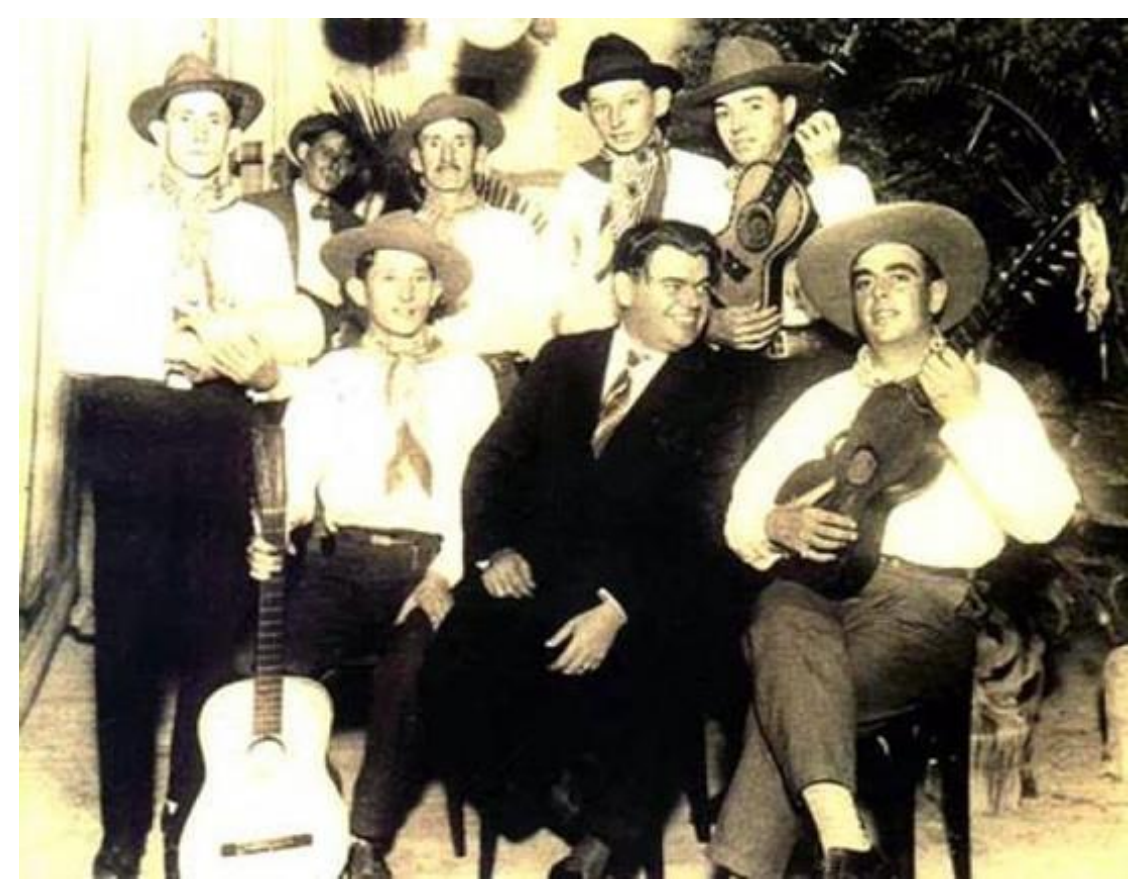

Imagem 3- "Turma Caipira Cornélio Pires". Da esquerda para a direita, em pé: Ferrinho, Sebastiãozinho, Caçula, Arlindo Santana. Sentados: Mariano, Cornélio Pires e Raul Torres (clichê do jornal “O Estado de São Paulo", de 5 de abril de 1929). (apud LOPES, 1999)

O processo elétrico de gravação em discos foi essencial para que Cornélio conseguisse os registros sonoros de causos e canções; contudo, enfrentou a resistência das gravadoras, só efetivando seu projeto com recursos próprios. A sua primeira produção foi um selo especial pela Columbia: a "Série Cornélio Pires" (1929), que incluía modas de viola, cururus e cateretês. Frente ao sucesso, a Columbia passou a apoiar a empreitada e continuou com a série lançando vários títulos?. Para tanto, formou a "Turma Caipira Cornélio Pires"8 o êxito de vendagem dos discos estimulou o interesse de outras gravadoras pelo gênero.

\footnotetext{
7 "Os discos saíram em maio de 1929, com 9 números de humorismo, interpretados pelo próprio Cornélio Pires, e mais três danças paulistas, um samba paulista, um desafio e intercalados uma cana-verde e um cururu (pela turma Caipira Cornélio Pires). Já no segundo Suplemento, de 5 discos, foi que a dupla Mariano e Caçula, da Turma Caipira Cornélio Pires gravou e lançou em outubro de 1929 a primeira Modade-viola, gravada no Brasil: "Jorginho do Sertão". (...) Cornélio e sua 'Turma Caipira' viajaram por vários municípios do interior de São Paulo. Fizeram apresentações na Capital, sempre com muito sucesso e tinham de repetir as apresentações, a pedido do público. (...) Gravou 104 músicas em 52 discos de 78 rotações, de 1929 a 1930. Esses discos, além de músicas da Turma Caipira Cornélio Pires, traziam música com Raul Torres, com o pseudônimo de Bico Doce e de Paraguaçu, com o pseudônimo de Maracajá, e também de outros artistas, que gravaram na 'Série Cornélio Pires' - discos de Selo Vermelho, que só Cornélio podia vender" (LOPES, apud PIRES, 2002 a, p. 13 - 14).

${ }^{8}$ Os integrantes da "Turma Caipira Cornélio Pires", em sua maior parte, eram do interior, alguns tinham sido trabalhadores na lavoura (Mariano, Caçula e Ferrinho), cortadores de cana (Bastiãozinho) e artesãos rurais (Arlindo Santana) (FERRETE, 1985, p. 70).
} 
Nas gravações, buscava recriar as narrativas mantendo o sotaque, a forma acaipirada de falar e se expressar nos relatos dos causos, histórias de humor e também através das canções. Nesse conjunto de expressões, o caipira era caracterizado por uma visão de mundo singela, porém com uma esperteza singular.

Quem se mete a debochar o caipira quase sempre sai perdendo, pois ele com aquele seu jeitão de bobo, é fino como ele só e traz sempre a resposta pronta na ponta da língua. Foi o que aconteceu a um chofer que me conduzia de Tietê a Porto Feliz. Numa subida íngreme alcançamos um caipira que subia com o seu trole puxado por uma parelha de burro. Ao passarmos pelo caboclo, o chofer quis debochá-lo gritando:

- Oh, como é que você, com dois burros ficou pra trás homem?

- Num vá esquece que os meu burro anda na vará do trole. Os burros do tomóve anda na boleia. (PIRES, 1929 a, documento sonoro).

Com o sucesso dos discos, ampliaram-se os espetáculos e apareceram os programas de rádio ${ }^{10}$. Constituiu-se um movimento de reforço mútuo, a popularização pelo rádio auxiliou na divulgação das gravações e contribuiu para firmar o gênero; o número de apresentações cresceu, ampliando as perspectivas de difusão da cultura caipira (LEITE, 1996, p. 117).

Não foram muitas as participações de Pires nas rádios, ele teve um programa diário às 18h30, na Difusora (DUARTE, 2000, p. 141). Sua maior contribuição foi ter formatado (modelado) a estrutura desses programas (que se mantém reproduzida até os dias de hoje), que contavam com narração de causos, quadros humorísticos e de músicas (ARAÚJO, 2004, p. 10). Essa foi a interpretação concebida por Alceu Maynard em torno da pouco mencionada participação de Cornélio na vida artística do rádio.

\footnotetext{
9 "Diferentemente da rusticidade quase grosseira das gravações mecânicas, as anedotas e canções cômicas gravadas pelo processo elétrico, recriaram com mais precisão a fala acaipirada, e mostraram o lado astuto, divertido e simples do caipira paulista" (GONÇALVES, 2006, p. 144).

10 Em São Paulo, as transmissões radiofônicas se iniciaram nos anos de 1920, se expandindo nas décadas posteriores. $O$ rádio adquiriu centralidade comunicativa informando, divertindo e emocionando seus ouvintes. A programação das emissoras se tornou diversificada incluindo jornais, novelas, transmissões esportivas, programas humorísticos, religiosos e musicais, estes divulgavam uma música que se diversificava rítmica e poeticamente, acompanhando o mercado fonográfico. A programação musical incluía gêneros variados e visa atingir um público diversificado, incluindo os migrantes dos interiores, para os quais foram criados os programas caipiras/sertanejos que eram transmitidos bem cedo pela manhã e/ou ao cair da tarde; nestes, destacavam-se as músicas, violas e causos caipiras (MORAES, 1997; MORAES, 1999).
} 
Outra colaboração de Cornélio foi a introdução no mundo radiofônico de seu sobrinho, Ariovaldo Pires, que adotou o cognome de Capitão Furtado, que em 1939, lançou o "Arraial da Curva Torta", programa que era transmitido a partir do auditório da rádio Difusora, onde se buscava reproduzir o ambiente da roça (MARCONDES; BACCARIN, 2000).

Durante os 12 anos em que ficou no ar, lançou artistas como Hebe Camargo, que fazia dupla com sua irmã Estela (Rosalinda e Florisbela), o acordeonista ítalo-caipira Mário Zan, o sambista Blecaute (pseudônimo dado pelo Capitão, inspirando-se no racionamento de energia elétrica, durante a Guerra) e a dupla que alcançaria popularidade nunca antes experimentada por seus congêneres, Tonico e Tinoco. Os caipirinhas pobres, recém-chegados do interior, arrancaram 190 segundos de aplausos - cronometrados - ao final de um concurso para a contratação de violeiros para o “Arraial”, em 1943. (NEPOMUCENO, 1999, p. 282)

Em virtude do número reduzido de artistas do gênero para apresentações ao vivo, as gravações de Cornélio tornaram-se a base de vários programas sertanejos (FERRETE, 1985, p. 72). Dessa forma, o conjunto das ações de Pires (escritos em jornais e revistas, diversas publicações em prosa e poesia; espetáculos com anedotas, encenação, canções com a apresentação de violeiros e grupos musicais; gravações, atuações nas rádios e criação de um formato de apresentações caipiras) foi fundamental para possibilitar a circularidade de práticas culturais dos interiores (LEITE, 1996, p. 17).

Cornélio criou representações do caipira na cidade, ambientando seus personagens em experiências urbanas seja como migrante estabelecido ou só de passagem. O “Bonde Camarão", cantada por Mariano e Caçula, integrantes da "Turma Caipira Cornélio Pires", narrava

- Vaceis tivero em São Paulo, decerto se arregalarô por lá.

- Home, São Paulo é lindo, é uma buniteza, mai tem um tar Bonde de Camarão, fai chacoaia o corpo da gente lá dentro. Oh peste dos quinto, é pior do que carro de boi. Intão fizêmo uma moda de viola arrelachano ele. Escuite a moda.

Aqui em São Paulo o que mais me amola

É esses bonde que nem gaiola

Cheguei, abriro uma portinhola

Levei um tranco e quebrei a viola

Inda puis dinhêro na caixa da esmola! 


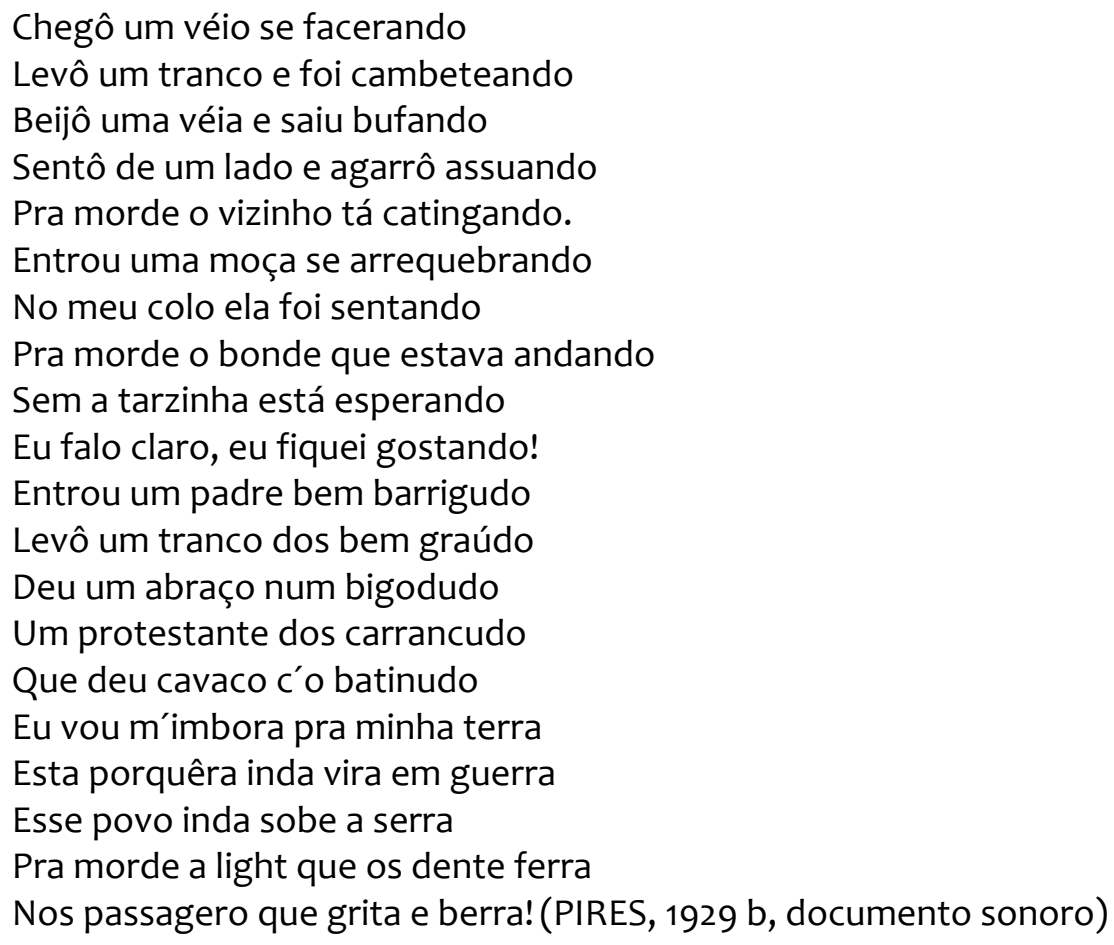

No início da canção", o narrador conta sua experiência na cidade, "Vaceis tivero em São Paulo, decerto se arregalarô por lá", assim, ele trazia o rural para o urbano e retornava para o rural, tendo como protagonista o caipira. Através do humor, explicitava encantamento, estranhamento contrastivo e hibridismo (CANCLINI, 2006).

\section{A cozinha caipira: alimentando o coração, a mente e a alma}

Ao sair após o almoção, um almoção paulista: feijão com couve, angu, torresmo, carne de porco e arroz-mole, fechando com um bom caldo de cambuquira... (PIRES, 2002 a, p. 75)

Alimentar-se é uma necessidade fisiológica, um imperativo biológico que atende às necessidades de sobrevivência, mas, também, que envolve construções simbólicas e culturais, assim, não se come apenas para saciar a fome e se nutrir, para saborear e por prazer. As pessoas se reúnem à mesa para além de se alimentar, socializar, conversar, comungar crenças, compartilhar sonhos, memórias e valores.

\footnotetext{
${ }^{11}$ Utilizar-se-á o termo canção em lugar de música "num sentido lato, isto é, abrangendo principalmente a letra, o universo que verbaliza cantando" (MARTINS, 1975, p. 117).
} 
Dessa forma, pretende-se focalizar gostos, hábitos, práticas e tradições alimentares dos caipiras, a partir dos escritos de Cornélio Pires, que nas ditas "conversas ao pé-do-fogo", buscou, ao recobrar experiências, evitar a desagregação da cultura caipira $^{12}$.

O sabor (o que se sente pelo paladar) diferencia-se do gosto, que é o resumo de várias experiências adquiridas e transmitidas culturalmente ${ }^{13}$. Enquanto uma construção cultural e histórica, o gosto é resultado de uma educação culinária, que por sua vez se inscreve na educação geral. A formação do gosto e a transmissão dos hábitos de alimentação são introduzidas na infância, em geral pela mãe, ou por quem prepara os alimentos. Neste processo, o gosto é constituído por estímulos gustativos, visuais, olfativos e, também, afetivos.

A memória dos sabores da meninice se mantém presente por toda a vida, os aromas e sabores desses pratos são inesquecíveis, "maravilhoso tesouro dos sabores da infância, sabores da felicidade perdida, doces sabores do passado" (CERTEAU, 1998), testemunhos que, apesar dos anos, não se perdem, sobrevivem e até resistem. Esses sabores e aromas marcantes emergem como "campainhas da memória”, que impregnam os corredores das reminiscências, constituindo-se em recordações afetivas que levam à busca de tempos perdidos, dos momentos de carinho, das demonstrações de afeição ou da espera ansiosa pela data festiva com suas guloseimas.

Mesmo frente ao distanciamento do ambiente familiar, o gosto, hábitos e práticas da cozinha são depositários e transmissores de cultura, elementos que dificilmente se

\footnotetext{
${ }^{12} \mathrm{~A}$ apreciação da obra de Cornélio Pires permite perceber que ele se colocava como um memorialista que visava preservar a cultura caipira (Tarrafadas/1932 e Sambas e Cateretês/1932), mas, também, como poeta (Musa Caipira/1910) e como literato, recriando experiências e personagens representativos (Joaquim Bentinho, o queima campo/1924, Conversas ao pé-do-fogo/1921). Para uma análise mais detalhada da obra de Pires, cabe atentar para a diversidade dos discursos produzidos em seus variados escritos, incluindo a liberdade criativa nas representações literárias e a forma da sua escritura (uso do "dialeto caipira", as questões da oralidade na transmissão de conhecimento, a intenção da produção humorística que emerge pelo contraste e estranheza) (SALIBA, 2002, p. 17 e AMARAL, 1920).

${ }_{13}$ As palavras: gosto, paladar e sabor apresentam diferenças sutis em seus significados e às vezes se confundem, podendo ser consideradas como sinônimos, conforme o contexto em que são empregadas. O "gosto" tem o sentido pelo qual se percebe o sabor das coisas; enquanto o termo "sabor" emprega a impressão que as substâncias produzem na língua ou propriedade que tem tais substâncias de impressionar o paladar. Já o termo "paladar" tem o sentido anatômico de palato, a região do céu da boca, sensível ao sabor. $O$ gosto define para um grupo social suas escolhas, que se impõem como hábito às demais manifestações culturais.
} 
apagam, tornando-se reveladores das origens e propiciando o reconhecimento das pessoas da mesma cultura. Entre os diferentes tipos de memória (específica, étnica e artificial) o gosto e as práticas da cozinha constituem elementos da étnica, a dita “cozinha da memória” (HERVÉ, 2002), que possibilita o reconhecimento entre os membros de uma cultura, através do uso de ingredientes e de procedimentos, que atendem a um gosto específico. Esses elementos são portáveis e tornam-se um dos últimos costumes abandonados, podendo ser considerado até um fator de resistência e referencial de identidade, reproduzido pelo ditado "diga-me o que comes que eu te direi quem és."14

O cozinhar é um ato cultural (SANTOS, 2005), abrangendo sistemas de valores com escolhas e gostos, alimentos apreciados, rejeitados e preferidos, envolvendo procedimentos, códigos e regulamentos, práticas e preceitos, tradição, constituindo-se em habitus (BOURDIEU, 1988). Dessa forma, se mantêm como elementos da memória, representações simbólicas do passado, traduzindo o sentimento de pertença, integração, reconhecimento e escolha, já que o que uns comem se diferencia do que os outros apreciam.

A composição do cardápio e preparo dos alimentos subentende um processo cultural complexo que abarca várias etapas: eleição dos produtos (códigos de aceitação, rejeição e tabus), classificação, acesso aos ingredientes, técnicas e processos de preparo (grelhar, assar, fritar ou cozinhar), condimentação e conservação, também, as formas de servir e apresentar à mesa. Cozinhar implica em fazê-lo para alguém, para os outros membros da família ou do grupo, estando a permanência de uma receita atrelada a sua capacidade de agradar.

Os saberes da cozinha caipira foram transmitidos de geração a geração, entretanto, da tradição escrita, pouco restou. A elaboração dos pratos era/é majoritariamente automática, mantendo-se como parte dos costumes e elemento da

\footnotetext{
${ }^{14}$ Cabe lembrar que os tropeiros paulistas foram os responsáveis pela divulgação dos hábitos alimentares dos caipiras para outras regiões do país. Essas práticas passaram por processos de apropriação em regiões como Minas Gerais, Mato Grosso e norte do Paraná.
} 
memória, com práticas, hábitos recebidos e transmitidos oral e empiricamente ${ }^{15}$. Os registros em cadernos de receitas ou manuscritos são raros, a falta de hábito de registro talvez se deva à baixa escolaridade, principalmente feminina, que inviabilizava a manutenção de um caderno de receitas, ou se existiram alguns, foram perdidos no tempo. Além do mais, as receitas eram constantemente modificadas, tanto quanto os ingredientes, como os procedimentos utilizados, não somente por ausência de registros, também, pela criatividade-inovação-possibilidades de quem cozinha. Dessa forma, os escritos de Cornélio se tornam documentos com potencial para levantar questões dessa temática.

\section{Cozinha caipira: tradições e desafios}

Cada povo come segundo sua alma, antes talvez que segundo seu estômago. (BOURDIEU, 1988)

Cornélio, num conjunto de menções, resgatou as práticas cotidianas nas mesas dos interiores:

Depois de um bom jantar: feijão com carne-seca, orelha de porco e couve com angu, arroz-mole engordurado, carne de vento assada no espeto, torresmo enxuto de toicinho da barriga, viradinho de milho verde e um prato de caldo de couve, jantar encerado por um prato fundo de canjica com torrões de açúcar. Nhô Thomé saboreou o café forte e se estendeu na rede. A mão direita sob a cabeça, à guisa de travesseiro, o indefectível cigarrão de palha entre as pontas do indicador e do polegar, envernizados pela fumaça, de unha encanoadas e longas, ficou-se de pança para o ar, modorrento, a olhar as ripas do telhado..."quem come e não deita, a comida não aproveita”, pensava Nhô Tomé... e pôs-se a cochilar. (PIRES, 2002 a, p. 48)

A cozinha é dinâmica, um processo que vai se transformando, se desconstruindo e se reconstruindo, baseado na tradição e, também, nos ingredientes disponíveis. Na

\footnotetext{
${ }^{15}$ A culinária, a partir do pressuposto de que, devido à ausência de alfabetização era transmitida oralmente, possibilitava a apreensão de um modo de vida. Dessa forma, problematizava uma forma de vivência característica, indicando a presença do desenvolvimento de conhecimentos alternativos ao da vida escolar. As receitas e as práticas do preparo não encontram um registro de patente, ou seja, não têm um criador específico. Fazem parte de um domínio coletivo do qual todos têm participação na medida em que adaptam ao cotidiano e às necessidades. A transmissão oral acabava por integrar a prática da narração, tão comum entre os caipiras, e que podia ser apreciada nas produções de Cornélio Pires, tanto escrita quanto em gravações sonoras.
} 
cultura caipira, as práticas e o consumo variavam de acordo com a abundância ou carência dos produtos e da sua sazonalidade, sendo que a composição do cardápio e preparo dos alimentos subentende um processo complexo que entre suas várias etapas inclui o acesso aos ingredientes (abundantes na região, produzidos, adquiridos, trocados, bem como os processos de conservação e armazenamento) ${ }^{16}$.

Não sendo vadio, o roceiro (e sua mulher, grifo dos autores) tem sempre o que comer, além do indispensável feijão com angu, ou farinha de milho - os seus inseparáveis arroz e torresmo. Cria galinhas e porcos além das cabras leiteira, salvação das crianças, nada lhe custa ter uma vaca de leite, ou duas, que se revezam ajeitando a época de leite por meio de barganhas e empréstimos.

Que mais falta?

Pouco distante da casa está o mandiocal, de mandioca-brava para raspas, farinha e tratamento de porcos; mais próximo o mandiocal de mandioca mansa, o aipim. Não faltam as tumbas de batata doce, branca ou roxa, de cará, de mangarito, de batatinha.

$\mathrm{Na}$ horta não faltam a couve, a alface, o repolho, o quiabo, o cará-de arvore, a ervilha, as favas, o feijão-guandu, o feijão de vara, a taioba, a mostarda, a aboboreira para "cambuquira" e abobrinhas, morangos e mogangas, o chuchu, o alho e as cebolas.

$\mathrm{Na}$ "roça", na mata e nos brejos, vegetam espontaneamente a gostosa "serralha", o margoso almeirão e o caruru; o palmito doce e as guarerova amargosa, agrião saudável.

Nos rios e riachos, abundantes peixes. Nos campos e nas grotas os veados, as capivaras, as pacas, as cotias, os tatus, os lagartos, os jaguaracambés, candimbas, os coelhos, os gambás e um dilúvio de aves aquáticas, como patos, marrecos e frangos d'água, além das pombas do mato e mais aves grossas.

Frutas em abundancia só não tem o vagabundo. Elas sazonam nos quintais, nas roças, nos pastos e nas matas - laranjas e pêssegos, maracujás e amoras, mangas e abacaxis, jambos, bananas, mamão e marmelos; melancias e melões, araticuns e gabirobas, pitangas e goiabas, jaracatiás e jabuticabas saborosíssimas, além de outras gostosas frutas silvestres (uvaia, gabiroba, mamão do mato ou gerequitiá, pitanga e amora). Além de tudo, na mata, há enorme variedade de mel para doce e remédio. (PIRES, 2002 a, p. 79-80)

\footnotetext{
${ }^{16}$ As receitas enraizadas vinculam-se à ideia de cozinhar bem e estão associadas à vida doméstica e às tradições. Através dessas receitas, podem-se decifrar códigos econômicos (produção e consumo), a recorrência de ingredientes (vinculada à produção local), favorecimento de certos produtos, mudanças e permanência de hábitos familiares, diferentes paladares, hábitos de comer frio ou quente, mais ou menos salgado, apimentado, pastoso ou sólido; também os sentimentos estéticos com suas diferentes maneiras de apresentar e servir.
} 
A própria horta era um território para o cultivo dos produtos apreciados que depois garantiam e complementavam o cardápio cotidiano e podia possibilitar um ganho extra com a venda dos excedentes. Assim sendo, muitas vezes os caipiras se dirigiam para as feiras ou "mercados caipiras" (como eram chamados) levando os produtos da horta e, também, os ovos, queijos e frutas, visando a obtenção de recursos extras ou de certos produtos, como sal, querosene, pão, trigo, entre outros.

Cabe diferenciar as práticas e alimentos preparados no cotidiano dos especialmente arranjados para os dias festivos ou de celebração. No cotidiano, a comida caseira possibilita uma sensação de prazer e aconchego, constituindo-se em elemento do habitus, com gosto, normas básicas, habilidades e regras culinárias apreendidos, subjetivados e transmitidos. Neste sentido, encontram-se referências constantes e identificação da tradição, bem como das rotinas cotidianas, horários das refeições e práticas alimentares dos caipiras

Diz-se que o caipira se alimenta mal, que a sua alimentação é insuficiente. Puro engano. Apesar de passar o dia no trabalho da lavoura, bate cada pratarrão! Vive ele a petiscar, a "lambiscar", quando passa o dia em casa. Nesse sentido o Nhô Tomé, com seu xale- manto sobre as costas abaulada. Chamou-se a atenção, ao sair mais um café - com - misturacafé com duas mãos, como dizem os roceros.

- Você não arrepare, no sítio a gente véve pra cumê, derd’o levanta inté no deitá. E entrou no assunto que aqui resumo.

Logo ao se levantar, um café simples, enquanto se prepara o que comer. Minutos depois café com leite, com bolo-de-frigideira, de fubá. Quando a mandioca cozida não substitui o pão...

Às 8:30 para 9:00 horas, o almoço; no meio dia, isto é, ás 11:30, café com mistura ou alguma fruta: às 2:30, jantar; às 5:00, merenda: as 7:30 para 8:00 horas, ceia. Tudo em abundancia, porque o pessoal tem sempre insaciável apetite! (PIRES, 2002 a, p. 79)

A dificuldade de acesso à carne bovina (mais usada em forma de charque e seca), colocava mais na mesa do caipira a carne de porco e de galinha, incorporadas à tríade milho, mandioca e feijão (com a adição do toucinho. O milho era empregado de forma variada, cozido nos pratos salgados e doces, verde ou seco (amadurecido e duro), em forma de farinha e bebida fermentada; também para alimentação dos animais e aves de terreiro. 
E os pratos caipiras? São variados. o caipira consome as carnes de porco e caça e raramente de vaca, em forma de charque de sal, sol ou de vento. Feijão com couve rasgada, ou picada, feijão-virado em farinha de milho, linguiça, arroz com suã de porco, com frango ou com aves selvagens, ou com entrecosto; couro pururuca de porco; torresmo, viradinho de milho verde, viradinho de cebola, virado de couve ou ervilha, palmito, batatas e ensopados de cará, serralha com muito caldo, cuscuz de lambaris, peixes, fritada em forma de tigeladas, bolo de fubá, bananinha de farinha de trigo, além de outros pratos. A refeição salgada é encerrada com um bom caldo de couve ou serralha, de palmito ou cambuquira...

Nhô Tomé tem razão... o caipira é menos carnívoro que nós outros, mas come por quatro... venha o leitor passar uns dias cá conosco e verá... (PIRES, 2002 a, p. 80-81)

Observa-se a incorporação no cardápio do caipira de produtos como abóbora, batata doce, cará; chicória, couve e serralha, carne da criação caseira, ovos, leite e seus derivados, peixe (pesca artesanal) e também a carne de caça (paca, tatu, lagarto, porco do mato, capivara, aves- macuco, codorna, frango do brejo entre outros). Acompanhava a sobremesa (frutas e doces), e também o hábito de beber a pinga e o café.

Durante as refeições usam os roceiros a água. Pelo meio dia a cachaça, os refrescos de marmelo, as limonadas, a água de açúcar, muito café, ou a jacuba empanzinadora, feita de água com açúcar mascado e farinha de milho. (PIRES, 2002 a, p. 81)

Quanto à doçaria caipira, se encontra atrelada à criatividade e habilidade feminina preparavam doces para oferecer de presente, receber uma visita e para as festas. Destacando-se os bolos (de mandioca, milho e fubá), paçoca de pilão e os doces de frutas, elaborados através das compotas, doces em calda, também na forma seca, cristalizada e geleias, tudo cuidadosamente preparado com as frutas “da época”, visando conservar o fruto colhido nos pomares ou quintais. O preparo implicava num trabalho árduo, envolvendo longos períodos mexendo os tachos ou panelões fumegantes para apurar o doce, sendo as habilidades femininas e o uso do fogão a lenha, o segredo dos sabores (FRANCISCO, 2004; MARINS, 2004).

Para sobremesa bastam o arroz doce, o melado com cará. A canjica, o curau, o milho verde cozido ou assado, o doce de abobora, de batata, de goiaba, de marmelo, ou o indefectível doce de cidra, furrundu (mamão e rapadura de cana), além dos variados doces de ovos e leite. (PIRES, 2002 a, p. 81) 
Além da elaboração dos pratos, as mulheres serviam a todos, trazendo as travessas com as comidas da cozinha para sala, ou do fogão à lenha para a mesa; raramente se sentavam ou eram as últimas a se acomodarem, e comiam sempre depois de todos.

Apesar das tradições se manterem no cotidiano, nos momentos festivos, elas eram postas à mesa. Nessas ocasiões, reuniam-se parentes e amigos para celebrar à mesa, saboreando, compartilhando e desfrutando dos pratos, sendo que, a própria preparação do alimento (muitas vezes coletivamente) se compunha numa celebração.

Nesses dias festivos, os pratos eram mais elaborados, receitas especiais, longas e trabalhosas. Assim ocorria nas festas de Natal, de Reis, festas aos santos de junho (Santo Antônio, São João, São Pedro), Festa do Divino, São Benedito e do santo padroeiro de alguma localidade. Essas ocasiões implicavam em práticas ritualísticas religiosas, como novenas, rezas, missas e procissões, também, incluindo um lado profano, com músicas, danças (quadrilhas), folguedos e comilança.

O caipira buscava em Santo Antonio a bênção para o alimento e para os casamentos; em São João, a proteção do plantio e a garantia da colheita farta; em São Pedro, a bênção para entrar nos reinos do céu ${ }^{17}$, além do apoio espiritual no Divino Espírito Santo. O festejar poderia ser na comunidade, junto à igreja ou na casa da família, que convidava outras pessoas (parentes, vizinhos e outros convidados), para desfrutar momentos e dividir a mesa, envolvendo regras de identificação e reforçando laços comunitários e de amizade.

Além dos momentos festivos, a comida também compõe a solidariedade no trabalho, através dos mutirões ${ }^{18}$.

\footnotetext{
${ }^{17}$ A partir dessas experiências foi criado o estereótipo caricaturado da "festa caipira" implicando no uso da indumentária colorida, estampa xadrez e remendos, vestido de chita e chapéu de palha, tendo a quadrilha como dança, ao som da sanfona, a encenação do casamento, acrescidos das delícias da mesa caipira com a valorização do uso do milho e dos doces.

18 “Muxirão, puxirão ou mutirão é a aplicação do auxílio mútuo, belo exemplo de solidariedade. Os lavradores da vizinhança, do bairro, determinam um dia e vão trabalhar gratuitamente para o mais necessitado, e, nesse único dia, fazem grandes roças. Algumas vezes fazem além da roçada, as capinações e colheita. Durante o trabalho, é costume cantar em coro, numa toada interessante e agradável. - É o trabalho e a festa ao mesmo tempo" (PIRES, 2002, a, p. 115). "Muchirão, mutirão s. m. - reunião de roceiros para auxiliar um vizinho nalgum trabalho agrícola - roçada, plantio, colheita terminando sempre em festa, com grande jantar ou ceia, danças..." (AMARAL, 1920, p. 133). Sobre a prática do mutirão, ver também (CANDIDO, 2010).
} 
O almoço de muxirão
- A alegria dos pobres dura pôco!
Chega-chega, moçada, a mesa é bôa.
despois do muxirão bamo no trôco,
que é estes frango co' arrois e uas leitôa.
- Despois do armoço nóis vae vê, caboco,
de quantos pau se faix ua canôa!
grita um caipira barbaçudo e rouco:
- Dois arquere de róça é coisa atôa!
- Me dê a serraia - Intão, nho Benedicto, num qué porvá ûa coxa de cabrito?
- Passe o frango, nho Tico? - Passe a pinga...
E o dono do sitiéco, enthusiasmado:
- Coma-coma, meu povo, que o roçado
é um capoeirão, num é restinga... (PIRES, 1985, p. 43)

O poema que representa o mutirão possibilita perceber a sociabilidade, a dádiva e as práticas culinárias (alimentos oferecidos em fartura como frango, leitão, cabrito e pinga). No mutirão, o grupo ajudava no roçado ou na colheita; em agradecimento pelo trabalho realizado, se ofertava o alimento para repor as energias e também como forma de confraternização, como no dizer de Cornélio, "mutirão é trabalho e festa ao mesmo tempo".

Para o cerimonial da morte, também se compunha um cardápio. O “Beber o morto" era tradição antiga; o velório era um momento solene, de rememorar/honrar o falecido, de consolar as famílias e de confraternização entre os vivos, de ajudar a família. Velavam-se os mortos em casa, na sala; sobre uma mesa, ficavam o caixão, velas acesas ao redor e cadeiras para acomodar parentes e amigos. Eram cerimônias longas (podendo se estender pela noite), velando e rezando, sendo costume oferecer comida (derivados de milho, como bolo de fubá, pamonha doce e salgada, biscoitos), chá, café e a cachaça. Havia, como forma de homenagem, o ritual de "beber" ao morto. Antes de beber, havia o costume de "lavar o pé", que consistia em derrubar um pouco da bebida no pé para afastar a morte.

Não é só no festejar que o caipira manifesta hospitalidade; ele, ao receber, oferece o que comer, sendo essa dádiva, uma forma de manifestar gentileza, cortesia e acolhimento, que estão enraizados na cultura (PERROT, 2011; RAFFESTIN, 1997). 
O caipira, sempre cortês, sempre gentil, convidou:

- Bamo apiá... a vila é perto... Inquanto dá um fórgo pra seu cavalo, amia ele, que tá balanceano a cansera.

O rapaz apeou-se.

- E agora - continuou o amável caipira - mecê espére um pocô, janta cum nóis e inda vai chega c'o sór na vila. Despois da janta eu iê acumpanho inté na incruziada pra iê insiná o caminho.

O rapaz aceitou...

O próprio dono da casa "pôs a mesa", estendendo a meia toalha de algodão, muito limpa. Trouxe o garfo de cabo de madeira e colheres de ferro, ainda com pingos de estanho aqui e ali, derretidos ao apanharem brasa com a colher, para acender cigarros.

Depositou em frente ao lugar do hóspede a única faca, muito fininha, muito gasta, com que picavam couve, tendo no cabo, de madeira preta, encrustada uma figura de chumbo, semelhante à pinta de paus, do baralho.

Trouxe depois dois pratos de louça pombinho, roxos, meio trincados, depôs no meio da mesa um travessa fundo, desbeiçado, de louça azul, cheio de feijão; um travessa raso, de ramos de rosa, cheio de arroz; um prato fundo com couve e dois rasos, com torresmo e mandioca; despejou na toalha uma cuia de farinha de milho amarelo, bijulenta e convidou:

- Puis intão cheguemos... é cumidinha de póvre, mais dá para incostá u estamo...Se vancê tivesse chagado mais cedo, dava pra tê matado u'a leitoa. (PIRES, 2005, p. 30-31)

O texto permite observar o que se serve e o que se come, incluindo como se come, os hábitos e utensílios de uso à mesa, abrindo a possibilidade de se questionar sobre o próprio espaço da cozinha.

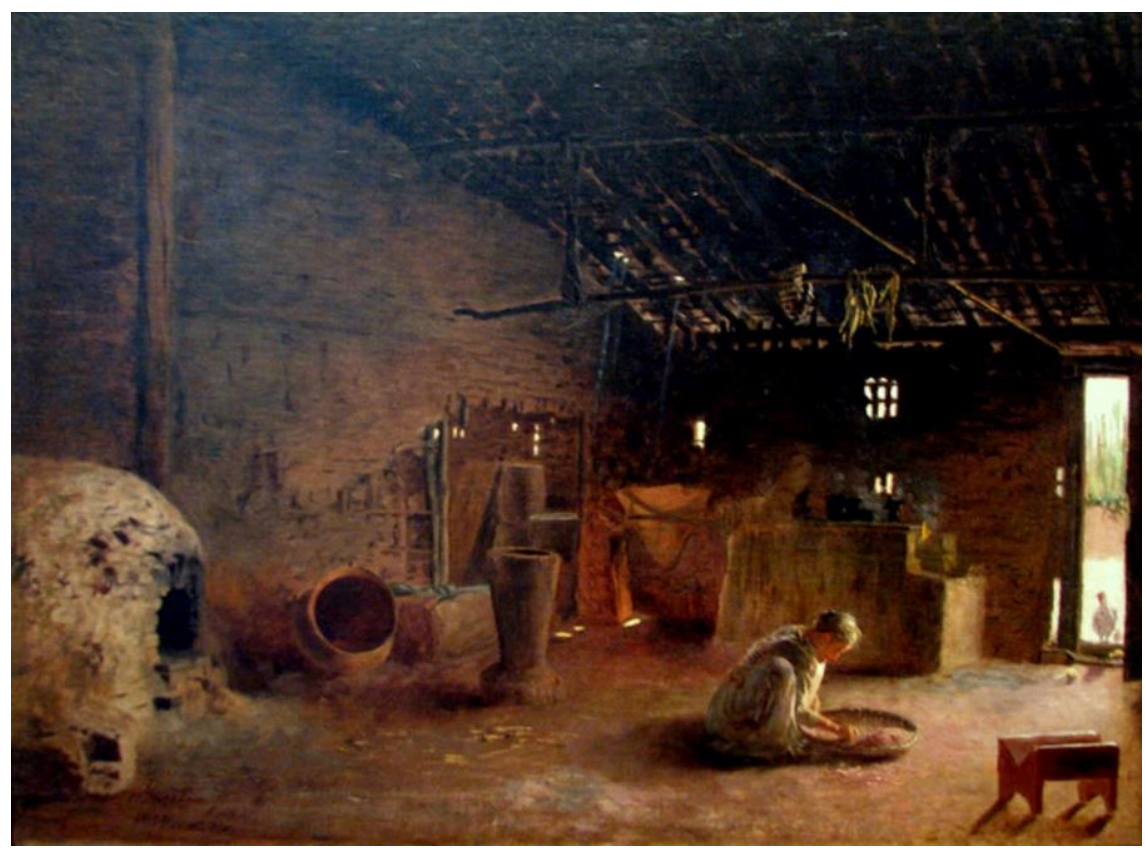

Imagem 4: Cozinha caipira, Almeida Júnior, 1895. 
Na tela, o que se vê, é uma representação da cozinha caipira; ao centro, sentada no chão de terra batida, de cócoras, destaca-se a figura feminina esguia, cabelos esbranquiçados apanhado em um coque, humildemente vestida. A mulher encontra-se entregue a sua tarefa doméstica, selecionando os grãos na peneira, seus movimentos parecem lentos e cuidadosos.

O ambiente caracterizado é rústico, paredes de taipa e teto sem forro; pela porta entreaberta, que leva ao exterior, uma galinha penetra com os seus pintinhos. Num canto, o fogão à lenha; sobre ele, carnes e embutidos pendurados para secar ou defumar e vários outros utensílios de barro ou ferro sobre a grelha; do outro lado, o forno de barro, ambos enegrecidos pelo uso. Ao fundo, um caixote ou arca tem ao seu lado um pilão de madeira (que era usado para moer, triturar, pilar, descascar arroz, milho, sal, açúcar, entre outros); também se destaca um objeto bojudo, espécie de caldeirão, com várias possibilidades de uso.

A cozinha caipira era um lugar de armazenamento e conservação, limpeza e preparo cocção e serviços gerais; esse cômodo era construído nos fundos ou fora do corpo principal da casa. Nela, o fogão à lenha, equipamento fixo, tinha um papel de destaque na definição do espaço, pois seu uso produzia sujeira, cinza, fuligem e fumaça que enegreciam as paredes, caracterizando esse espaço de forma diferenciada do que se conhece na cozinha higienizada (MENESES, 2000; SILVA, 2007; CARVALHO, 2004).

Entre os utensílios utilizados cotidianamente na cozinha, se incluíam peças (potes, tachos, panelas, caçarolas, frigideiras, caldeirões, moringas, gamelas) que poderiam ser de barro, ferro ou cobre, madeira e raiz de árvores; torradores de café, cuscuzeiros, suportes de coadeiras de café, objetos em ágata (canecas, bule, pratos, copos), louças e cuias, móveis rústicos de madeira (guarda comidas, arcas, banquetas, baús), cestos e peneiras de palha ou taquara, lampião ou candeeiro a querosene, lamparina a óleo e outros (SILVA, 2007; LEMOS, 1978).

Os trabalhos na cozinha eram atividades árduas, pesadas e demoradas, exigiam competência no preparo dos pratos e uso dos equipamentos. Para se cozinhar no fogão e no forno à lenha eram necessárias habilidades para graduar e controlar a temperatura, perícia para usar as grelhas e chapas de ferro, nas quais eram colocadas as panelas sobre 
aberturas próprias; conhecimento para acompanhar o cozimento, controle do tempo de preparo para evitar que a comida ficasse crua ou queimada e que ficasse pronta no horário cotidiano das refeições. Os serviços na cozinha ocupavam o dia todo; levantava-se de madrugada para acender o fogão à lenha e logo começava a lida na sequência das refeições (café da manhã, almoço, ceia, lanches e merendas) (MATOS, 2014; CARVALHO, 2004).

Além do preparo do alimento, os serviços femininos na cozinha incluíam pilar e moer o milho, arroz, sal e açúcar; pilar, torrar e moer o café. Acrescidos do abate, limpeza e preparação de aves e animais (preparar a banha e os embutidos, conservar as carnes na banha e defumá-las), tirar leite, preparar manteiga e queijos, e até fazer sabão e vela. 0 trabalho doméstico implicava em ciclos intermináveis de plantar, tratar, colher e comer, que abarcavam ainda o trato do galinheiro e do chiqueiro, da horta e do pomar.

\section{Considerações finais}

As inquietações em torno da constituição do trabalhador "nacional" envolveram debates e geraram polêmicas, constituindo um terreno fértil no qual Monteiro Lobato "inventou" a figura do Jeca Tatu - uma representação do homem do campo, realçando seus aspectos negativos. Foi também neste contexto que se destacou Cornélio Pires, cuja ampla produção (escritos, gravações e apresentações) difundiu e valorizou a cultura caipira.

Na obra de Cornélio, emergem diversificadas e ambíguas representações do rural e do homem dos interiores. Por um lado, ele valorizava o caipira, representando-o romantizado com sentimentos positivos e atitudes simples, autênticas, sinceras e cordiais, enfrentando cotidianamente o trabalho agrícola; por outro, o caipira também foi caricaturado por seus comportamentos impróprios, sendo apresentado em situações de comicidade.

No conjunto da sua obra, Cornélio vislumbrou os perigos de um processo de extinção da cultura caipira; frente a isso, ele se colocou como um agente de preservação desse patrimônio, sendo seus esforços, contribuições fundamentais para registrar e divulgar valores, hábitos, escritos, narrativas, músicas e outras sonoridades dos interiores. 


\section{Referências}

ABUD, Kátia Maria. 0 sangue intimorato e as nobilíssimas tradições: a construção de um símbolo paulista: o bandeirante. 1985. Tese (Doutorado em História) - Universidade de São Paulo, 1985.

AMARAL, Amadeu. Dialeto Caipira. São Paulo: Casa Editora O Livro, 1920.

AMARAL, Aracy e LOUREIRO, M. Cecilia França. Almeida Júnior: um artista revisitado, São Paulo, Pinacoteca do Estado, 2000.

ARAÚJO, Alceu Maynard. Cornélio Pires: O bandeirante do folclore paulista. In: AS

ESTRAMBÓTICAS aventuras de Joaquim Bentinho: o queima-campo, Cornélio Pires. São Paulo:

Editora Ottoni, 2004.

BARTHES, Roland. Rhétorique de l' image. Communications, Paris, n. 4, Seuil, 1964.

BOURDIEU, Pierre. La distinción: criterios y bases sociales del gusto. Madrid: Taurus. 1988.

CAMARGOS, Márcia. Semana de 22: entre vaias e aplausos. São Paulo: Boitempo, 2002.

CANCLINI, Néstor García. Culturas híbridas: estratégias para entrar e sair da modernidade. São Paulo: EDUSP, 2006.

CANDIDO, Antonio. Os parceiros do Rio Bonito: estudo sobre o caipira paulista e a transformação dos seus meios de vida. Rio de Janeiro: Ouro sobre azul, 2010.

CARVALHO, Luiz Gonzaga Assumpção. Do fogão a lenha ao micro-ondas: uma incursão pela comensalidade de três gerações de famílias paulistanas. Dissertação (Mestrado em hospitalidade) - Universidade Anhembi Morumbi, São Paulo 2004, n. pgs 213.

CASTANEDA, Luzia. Da eugenia à genética: alcoolismo e hereditariedade nos trabalhos de Renato Kehl. In: SEMINÁRIO NACIONAL DE HISTÓRIA DA CIÊNCIA E DA TECNOLOGIA, 6. 1997. Anais [...]. Rio de Janeiro, Sociedade Brasileira de História da Ciência, 1997.

CERTEAU. Michel de. A invenção do cotidiano 2: morar, cozinhar. Petrópolis: Ed.Vozes, 1998.

COLI, Jorge. Como estudar a arte brasileira do século XIX? São Paulo: Editora SENAC, São Paulo, 2005.

CONTRERAS, Jesús. Antropología de la alimentación. Madrid: Eudema. 1993.

DANTAS, Macedo. Cornélio Pires: criação e riso. São Paulo: Duas Cidades, Secretaria da Cultura, Ciência e Tecnologia, 1976.

DIWAN, Pietra Stefania. O espetáculo do feio: práticas discursivas e redes de poder no eugenismo de Renato Khel 1917-37. Dissertação (Mestrado em História) - PUC/São Paulo, 2003, n. pgs 175.

DUARTE, Geni Rosa. Múltiplas vozes no ar: o rádio em São Paulo nos anos 30 e 40. Tese (Doutorado em História) - PUC/SP, 2000, n. pgs 254. 
ELLIS JUNIOR, Alfredo. O café e a Paulistânia. São Paulo: Editora da USP, 1951.

FERREIRA, Elton Bruno. Sonoridades caipiras na cidade: a produção de Cornélio Pires (1929-1930). São Paulo: E-manuscrito, 2017.

FERRETE, J. L. Capitão Furtado: viola caipira ou sertaneja? Rio de Janeiro: Funarte, 1985.

FRANCISCO, Luis Roberto. A gente paulista e a vida caipira. In: TERRA PAULISTA: história, arte e costumes. São Paulo, CENPEC/Imprensa Oficial, 2004, p. 23-51.

GONÇALVES. Camila Koshiba. Música em 78 rotações: "discos a todos os preços” na São Paulo dos anos 30. Dissertação (Mestrado em História) - Universidade de São Paulo, SP, 2006, p. 232.

HERVÉ, This. Traité elémentaire de cuisine. Paris: Éditions Belin. 2002.

Imagem 1. Caipira picando fumo, de Almeida Júnior,1893.

Imagem 2. Capa do Almanaque Jeca Tatuzinho, de Monteiro Lobato, 12 ${ }^{\mathrm{a}}$ edição, 1941.

Imagem 3. "Turma Caipira Cornélio Pires". Clichê do jornal "O Estado de São Paulo", de 5 de abril de 1929, apud LOPES, 1999.

Imagem 4. Cozinha caipira, de Almeida Júnior, 1895.

JOLY, Martine. Introdução à análise da imagem. Campinas: Papirus, 1996.

LAJOLO, Marisa P. Monteiro Lobato: um brasileiro sob-medida. São Paulo: Editora Moderna, 2000.

LEITE, Sylvia Helena Telarolli de Almeida. Chapéus de palha, panamás, plumas, cartolas: a caricatura na literatura paulista, 1900-1920. São Paulo: Unesp, 1996.

LEMOS, Carlos A. C. Cozinhas, etc: um estudo sobre as zonas de serviço da casa paulista. São Paulo: Perspectiva, 1978.

LOBATO, Monteiro. Urupês. Rio de Janeiro: Globo, 2010.

LOPES, Israel. Cornélio Pires: Um pouco de sua vida e de sua obra. In: CONVERSAS ao pé-do-fogo: Cornélio Pires. São Paulo: Ottoni, 2002.

LOPES, Israel. Turma Caipira Cornélio Pires: os pioneiros da “moda de viola” em 1929. São Borja: M\&Z Computação Gráfica, 1999.

LUCA, Tania Regina de. Leituras, Projetos e (Re)vista(s) do Brasil: 1916-1944. São Paulo: Unesp, 2011.

MANGUEL, Alberto. Lendo imagens. São Paulo: Cia. das Letras, 2008. 
MARCONDES, Marcos y Biaggio Baccarin. Enciclopédia da música brasileira: sertaneja. São Paulo: Art Editora, 2000.

MARINS, Paulo Cesar. A vida cotidiana dos paulistas: moradias, alimentação indumentária. In: TERRA paulista, modos de vida dos paulistas: identidades, famílias e espaços domésticos. São Paulo, CENPEC/Imprensa Oficial, 2004. pp. 89-185.

MARQUES, Vera Regina Beltrão. A medicalização da raça: médicos educadores e discursos eugênicos. Campinas: Unicamp, 1994.

MARTINS, José de Souza. Música sertaneja: dissimulação na linguagem dos Humilhados. In: CAPITALISMO e Tradicionalismo: estudos sobre as contradições da sociedade agrária no Brasil. São Paulo: Pioneira, 1975, 103-161.

MATOS, Maria Izilda Santos de. A cidade, a noite e o cronista: São Paulo de Adoniran Barbosa. São Paulo, EDUSC, 2007.

MATOS, Maria Izilda Santos de. Corpos e emoções: história, gênero e sensibilidades. São Paulo: Emanuscrito, 2018.

MATOS. Maria Izilda Santos de. Cotidiano e cultura. 3.ed. São Paulo, E-manuscrito, 2019.

MENESES, Ulpiano T. Bezerra de. O fogão da Societé Anonyme du Gás: sugestões para uma leitura histórica de imagem publicitária. Projeto História, São Paulo, n. 21, 2000, p. 105-119.

MORAES, José Geraldo Vinci de. Rádio e música popular nos anos 30. Revista de História 140, 1999, p.75-93.

MORAES, José Geraldo Vinci de. Sonoridades paulistanas: a música na cidade de São Paulo: final do século XIX ao início do século XX. Rio de Janeiro: Funarte, 1997.

NEPOMUCENO, Rosa. Música Caipira: da roça ao rodeio. São Paulo:

Editora 34, 1999.

NIGRI, André. Monteiro Lobato e o racismo. Revista Bravo!, n. 165, 2011, p. 24-33.

OLIVEIRA, Lúcia Lippi. Os italianos e os modernistas paulistas. In : Encontro da ANPOCS, 26. Anais [...]. Minas Gerais, Associação Nacional de Pós-graduação e Pesquisa em Ciências Sociais (ANPOCS), 2002. Disponível em:

www.anpocs.org/portal/index.php?option=com_docman\&task=doc_view\&gid=4426\&ltemid=317. Acesso em:12/02/2015.

PAIVA, Eduardo. História e imagens. Belo Horizonte: Autêntica, 2004.

PEREIRA, Sonia Gomes. Revisão historiográfica da arte brasileira do século XIX. Revista do Instituto de Estudos Brasileiros, São Paulo, n. 54, USP, set./mar. 2012. Disponível em: www.revistas.usp.br/rieb/article/download/ 49114/53192. Acesso em: 15/03/2016 
PERROT, Danielle. Dádiva, hospitalidade e reciprocidade. In: A. MONTANDON. O livro da hospitalidade: acolhida do estrangeiro na história e nas culturas. São Paulo: Senac São Paulo. 2011.

PICCHIA, Menotti del. Juca Mulato. São Paulo: Casa Editora “O Livro", 1921.

PIRES a, Cornélio. A Rebatidas de caipiras (trecho). São Paulo: Columbia, 1929. 1 disco vinil 78 rpm. Anedota gravada por Cornélio Pires.

PIRES b, Cornélio. O Bonde Camarão. Disco moda de viola. São Paulo: Columbia, 1929. 1 disco vinil $78 \mathrm{rpm}$.

PIRES, Cornélio. As estrambóticas aventuras de Joaquim Bentinho: O queima-campo. São Paulo: Editora Ottoni, 2004.

PIRES a, Cornélio. Conversas ao pé-do-fogo. Itu: Editora Ottoni, 2002.

PIRES, Cornélio. Meu Samburá. Itu: Ottoni Editora, 2005.

PIRES, Cornélio. Musa caipira. Tietê: Prefeitura Municipal de Tietê, 1985. Edição comemorativa do centenário de nascimento do autor (1884-1984).

PIRES b Cornélio. Patacoadas. São Paulo: Ottoni, 2002.

RAFFESTIN, C. Réinventer I’hospitalité. Communications, n.65, 1997. p.165-174.

RICARDO, Cassiano. Borrões de verde amarelo. São Paulo: Editorial Helios, 1925.

RICARDO, Cassiano. Martim Cererê ou o Brasil dos meninos, dos poetas e dos heróis. São Paulo: Editorial Helios, 1928.

SALIBA, Elias Thomé. Raízes do riso: a representação humorística na história brasileira: da Belle Époque aos primeiros tempos do rádio. São Paulo: Companhia das Letras, 2002.

SANCHES, Durce Gonçalves, O modo de vida do caipira em obras de Almeida Jr.

Dissertação (Mestrado em Comunicação e Cultura) - Universidade de Sorocaba, 2010. N. pgs 257.

SANTOS, Carlos R. A. Alimentação e seu lugar na história. Revista História: Questões \& Debates: História da Alimentação, Editora UFPR. Ano 22, n. 42, 2005.

SCHWARCZ, Lilia Moritz. Sobre uma certa identidade paulista. In: CAMARGO, Ana Maria de Almeida (Org.). São Paulo, uma viagem no tempo. São Paulo: CIEE, 2005, p. 153-170.

SILVA. João Luiz Máximo da. Transformações no espaço doméstico: o fogão a gás e a cozinha paulistana, 1870-1930, São Paulo. In: ANAIS do Museu Paulista, v. 15, n.2, 2007. 
SOUZA a, Vanderlei Sebastião. A política biológica como projeto: a ‘eugenia negativa' e a construção da nacionalidade na trajetória de Renato Kehl (1917-1932). Dissertação (Mestrado em História) - Casa de Oswaldo Cruz, 2006, n. pgs 218.

SOUZA b, Vanderlei Sebastião. Em nome da raça: a propaganda eugênica e as ideias de Renato Kehl nos anos 1910 e 1920. Revista de História Regional, v.11, n. 2, 2006, p. $29-70$.

STEPAN, Nancy Leys. A hora da eugenia: raça, gênero e nação na América Latina. Rio de Janeiro: Editora Fiocruz, 2005.

VELLOSO, Mônica Pimenta. O mito da originalidade brasileira: a trajetória intelectual de Cassiano Ricardo (dos anos 20 ao Estado Novo). Dissertação (Mestrado em Filosofia) - Pontifícia Universidade Católica do Rio de Janeiro, 1983, n. pgs 190.

ZEM EL-DINE, Lorenna Ribeiro. Raça, história e política em Alfredo Ellis Jr. e Cassiano Ricardo. Dissertação (Mestrado em História) - UFES, 2010.

Recebido em 26/04/2018 Aprovado em 26/02/2019

Universidade do Estado de Santa Catarina - UDESC Programa de Pós-Graduação em História - PPGH Revista Tempo e Argumento Volume 11 - Número 27 - Ano 2019 tempoeargumento@gmail.com 